\title{
Collaboration Planning by Task Analysis in Human-Robot Collaborative Manufacturing System
}

\author{
Jeffrey Too Chuan Tan, Feng Duan, \\ Ryu Kato and Tamio Arai \\ University of Tokyo \\ Japan
}

\section{Introduction}

The shifting manufacturing requirements to high flexibility and short production cycle have urged the emerging of human-robot collaborative type of manufacturing systems. Humanrobot collaboration is a dream combination of human flexibility and machine efficiency. However, in order to materialize this paradigm shift in manufacturing history, the interaction between human and robot in the perspective of collaborative operation has to be fully investigated. Many studies had been conducted in the area of human-robot collaboration in manufacturing (Kosuge et al., 1994; Oborski, 2004). Modeling techniques (Rudas \& Horvath, 1996) provide an initial step to study on this collaboration relationship even before system development. To ensure a more human-centered solution, task analysis is adapted for the modeling approach in this study. The purpose of this work is to develop a modeling framework based on task analysis approach to assist human-robot collaboration planning in manufacturing systems.

The entire development of this work is illustrated in a modeling development of an actual cable harness assembly in a prototype cellular manufacturing system (Duan et al., 2008). The outline of the paper is arranged as the following: Section 2 provides the literature reviews on human-robot collaboration in manufacturing and the overview of the prototype cellular manufacturing system setup together with the assigned cable harness assembly operation. Section 3 presents entire development of collaboration planning by task analysis including the brief introduction on task analysis approach, task decomposition by hierarchical task analysis, and collaboration analysis. Section 4 discusses the design enhancements by the modeling framework in operation process design and further extensions in human skill analysis, safety assessment and operation support. The modeling design is implemented in a prototype production cell to perform model validation and operation performance evaluation as illustrated in Section 5. Section 6 concludes the work and states the suggestions for future work. 


\section{Human-Robot Collaboration in Manufacturing}

\subsection{Human-Robot Collaboration}

Many efforts had been contributed in the study on human-robot interaction. Agah had presented a general taxonomy on human interaction with intelligent systems (Agah, 2000). In manufacturing environment, Stahre had discussed several human-robot interaction problems (Stahre, 1995). Over the years, there are many proposals on robotic human operator assistance: Robot Assistant rob@work (Helms et al., 2002), COBOT (Colgate et al., 1996), KAMRO (Karlsuhe Autonomous Mobile Robot) (Laengle et al., 1997), CORA (Cooperative Robotic Assistant) (Iossifidis et al., 2002), Humanoid Service Robot HERMES (Bischoff, 2001) and The Manufacturing Assistant (Stopp et al., 2002). Although much work had been conducted on human-robot interaction, the view point of this work is quite deviated from the common goal of these studies. The ultimate aim of this work is to improve manufacturing systems by effective human-robot collaboration, rather than how much 'social' between human and robot. Therefore, manufacturing requirements become the main criterion in the collaboration planning. On the other hand, conventional assembly planning focuses on simplifying assembly process for automation. The lack in addressing human-robot collaboration in design for assembly principles has motivated this work to develop a design approach to address human-robot collaboration in assembly planning.

\subsection{Practical Development in Cellular Manufacturing System}

In order to ensure practicability of this work, the entire development is linked on an actual cable harness assembly system in cellular manufacturing. Also known as cell production, cellular manufacturing is a human-centered production system that catered for complex and flexible assembly requirements (Isa, K. \& Tsuru, 2002). The prototype production cell design in this project is shown in Fig. 1 (Duan et al., 2008).

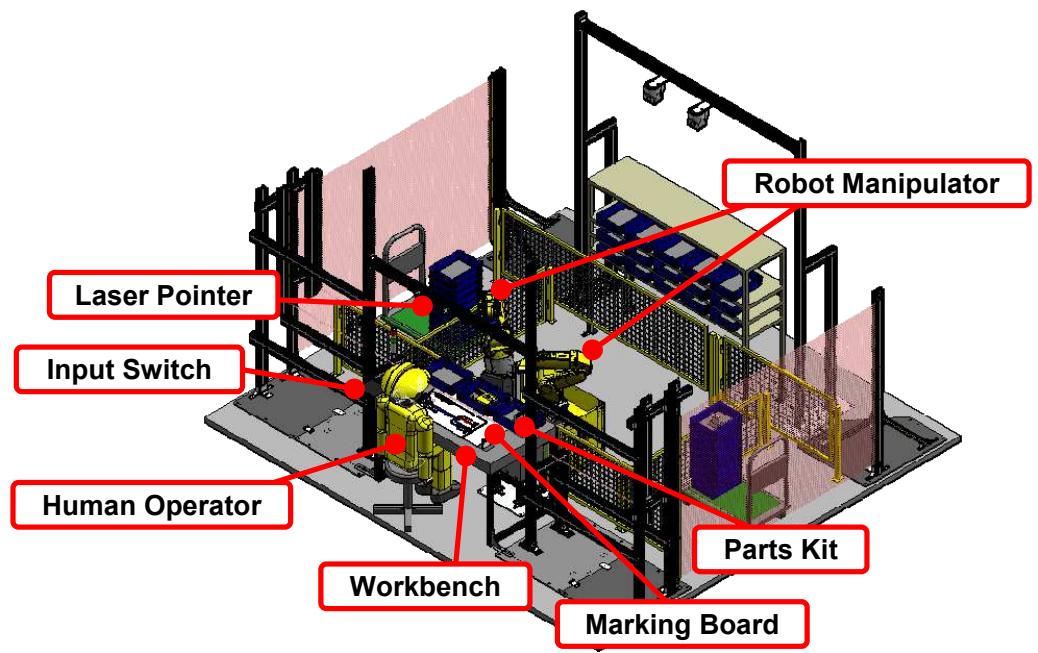

Fig. 1. Prototype production cell design for cellular manufacturing 
In this cellular manufacturing system, a mobile twin robot manipulators system is assigned to collaborate with a human operator to conduct a cable harness assembly operation (Fig. 2). The robot manipulators system is able to navigate itself within the production cell (between the parts rack and the workbench) and to facilitate collaborative assembly operations on the workbench. The human operator conducts the assembly operation in sitting position and uses the input switches to control the progress of the operation. The workbench is incorporated with a liquid crystal display television (LCD TV) to provide multimedia assembly information to the human operator. Additional position information is indicated by the laser pointer system. More detailed descriptions on the prototype production cell are available in Duan's work (Duan et al., 2008).

The completed cable harness assembly is shown in Fig. 2. The human operator assembles components from the parts kit onto the marking board to form the product. The required tasks in one assembly includes cable insertion on connector and terminal, tape marking and cable tie binding, and the assembly of metal plate. This assembly process will be discussed further in the following section for collaboration planning.

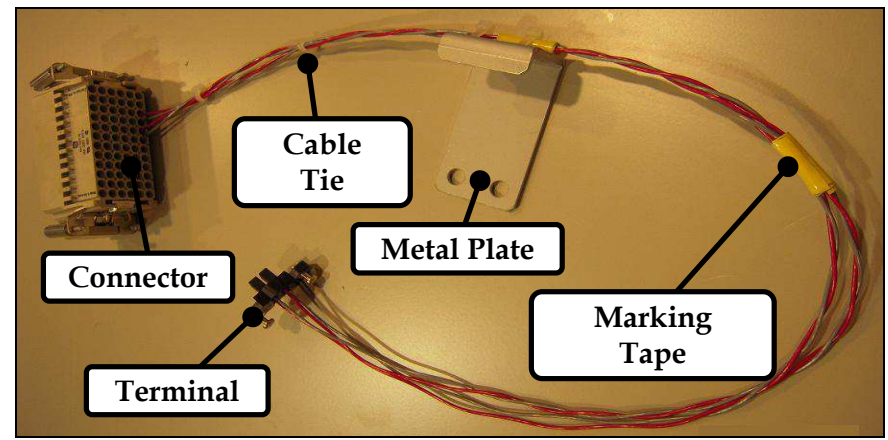

Fig. 2. Cable harness assembly

\section{Collaboration Planning by Task Analysis}

\subsection{Task Analysis}

The main challenge in human-robot collaboration study is the complexity of human nature because normal mathematical computer modeling techniques are difficult to study on the behavior. Many research studies developed the collaboration modeling from the 'machine' point of view (Kosuge et al., 1998; Mizoguchi et al., 1999) resulting 'machine-driven' collaboration. Therefore, with the motivation to develop a more 'human-centered' collaboration in production system, this work has adopted task analysis method, which provides a more 'natural' way to define and study on human activities. Task analysis is a widely used scientific methodology to model human task in various ergonomics and human factors studies (Hodgkinson \& Crawshaw, 1985), medical surgery (Sarker et al., 2008), error prediction (Lane et al., 2006), and software interface design (Mills, 2007; Richardson et al., 1998). The main advantage of task analysis is the ability to describe human activities with 'abstract descriptions'. This temporal abstraction (Killich et al., 1999) is very useful in humanrobot collaboration modeling especially when the actual optimal sequence of activities is yet to be defined. In task analysis development, the task is defined as goal and the required 
activities (sub goals) that must be carried out to achieve it (Annett \& Duncan, 1967; Hollnagel, 2006), and continuous branch out in sub goals to form a hierarchical tree. This hierarchical task analysis (HTA) approach (Kirwan \& Ainsworth, 1992; Shepherd, 1998; Stanton, 2006) is adapted in this study to extend its capability to address human-robot collaboration in production systems. In the following discussion, the cable harness assembly operation is being decomposed into hierarchical assembly tasks tree to enable further investigation on the collaboration between human and robot in the collaborative operation.

\subsection{Task Decomposition by Hierarchical Task Analysis}

Fig. 3 shows the general operation flow of the cable harness assembly. The whole operation consists of mainly five different tasks. The first task is parts kit preparation, which is to gather all the required assembly components in the parts kit. The assembly begins with cable insertion to the connector in second task. In third task, the cables are being arranged on the marking board and bond with marking tape and cable tie. The purpose of the marking board is as a guide for the cables and assembly positions identifications. In the fourth task, the other ends of the cables are then inserted into the terminal. The final task is the metal plate assembly.

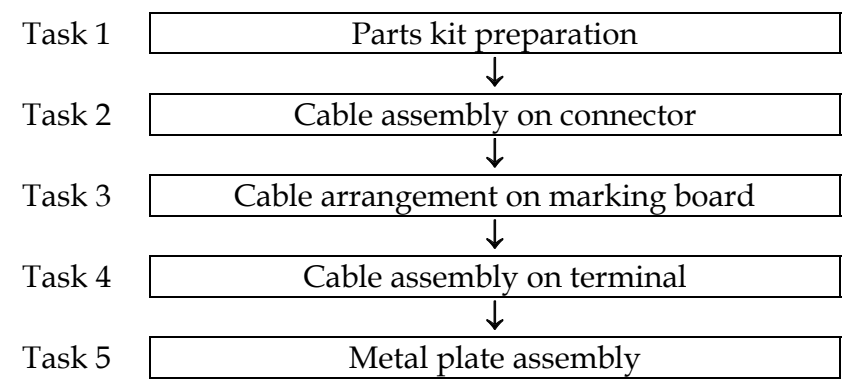

Fig. 3. General operation flow of the cable harness assembly

Referring to HTA development guideline by Stanton (Stanton, 2006), the entire cable harness assembly is being decomposed into hierarchical task tree (Tan et al., 2008a). The overall operation objective is set as the main goal followed by general tasks in the assembly plan level as the sub goals. Then, on each sub goals, the decomposition is further branched out into control plan level. Table 1 summarizes the decomposition of the cable harness assembly into a HTA table. 'Assemble cable harness' (Super-ordinate 0) is the main goal of the entire operation. Based on the general operation flow in Fig. 3, the first hierarchical level of sub goals, 'Prepare parts kit', 'Assemble cables on connector', 'Arrange cables on marking board', 'Assemble cables on terminal', and 'Assemble metal plate' (Super-ordinate 1, 2, 3, 4, and 5) are the general assembly tasks needed to achieve the main goal. The decompositions continue from the first level sub goals into another two hierarchical levels lower until all the task components are all well defined, as considered 'fit-for-purpose' (Stanton, 2006). In all the task levels, the execution sequence of the corresponding hierarchical level is defined in Plan components. With the developed HTA table, the entire cable harness assembly operation is well defined in a hierarchical task tree form for further development on collaboration 
planning. The HTA table can be represented in a graphical form for better visualization illustrated in the next section.

\begin{tabular}{|c|c|}
\hline Super-ordinate & Task components - Operation or Plan \\
\hline \multirow[t]{2}{*}{0} & $\begin{array}{l}\text { Assemble cable harness } \\
\text { Plan 0: Do } 1 \text { then } 2 \text { then } 3 \text { then } 4 \text { then } 5 \text { then exit }\end{array}$ \\
\hline & $\begin{array}{l}\text { 1. Prepare parts kit } \\
\text { 2. Assembly cables on connector } \\
\text { 3. Arrange cables on marking board } \\
\text { 4. Assemble cables on terminal } \\
\text { 5. Assemble metal plate }\end{array}$ \\
\hline \multirow[t]{2}{*}{1} & $\begin{array}{l}\text { Prepare parts kit } \\
\text { Plan 1: Repeat } 1.1 \text { then } 1.2 \text { for three parts then exit }\end{array}$ \\
\hline & $\begin{array}{l}1.1 \text { Arrange parts into tray } \\
1.2 \text { Check parts // }\end{array}$ \\
\hline \multirow[t]{2}{*}{1.1} & $\begin{array}{l}\text { Arrange parts into tray } \\
\text { Plan 1.1: Do 1.1.1 then 1.1.2 then exit }\end{array}$ \\
\hline & $\begin{array}{l}\text { 1.1.1 Retrieve part container // } \\
\text { 1.1.2 Grab part from container // }\end{array}$ \\
\hline \multirow[t]{2}{*}{2} & $\begin{array}{l}\text { Assemble cables on connector } \\
\text { Plan 2: Repeat } 2.1 \text { then } 2.2 \text { for two cables then } 2.3 \text { then exit }\end{array}$ \\
\hline & $\begin{array}{l}\text { 2.1 Secure cable contacts on connector } \\
\text { 2.2 Temporary fix cable ends // } \\
\text { 2.3 Set connector on marking board }\end{array}$ \\
\hline \multirow[t]{2}{*}{2.1} & $\begin{array}{l}\text { Secure cable contacts on connector } \\
\text { Plan 2.1: Repeat 2.1.1 then 2.1.2 then 2.1.3 for two cables then exit }\end{array}$ \\
\hline & $\begin{array}{l}\text { 2.1.1 Get cable from cable kit // } \\
\text { 2.1.2 Hold and locate insertion point // } \\
\text { 2.1.3 Insert cable contact into connector with driver // }\end{array}$ \\
\hline \multirow[t]{2}{*}{2.3} & $\begin{array}{l}\text { Set connector on marking board } \\
\text { Plan 2.3: Do 2.3.1 then } 2.3 .2 \text { then exit }\end{array}$ \\
\hline & $\begin{array}{l}\text { 2.3.1 Release connector // } \\
\text { 2.3.2 Get and place connector on marked location // }\end{array}$ \\
\hline \multirow[t]{2}{*}{3} & $\begin{array}{l}\text { Arrange cables on marking board } \\
\text { Plan 3: Do } 3.1 \text { for two cables then } 3.2 \text { for two marking tapes then } 3.3 \text { for two } \\
\text { cable ties then exit }\end{array}$ \\
\hline & $\begin{array}{l}\text { 3.1 Form cables on marking board } \\
\text { 3.2 Paste marking tape on cables } \\
\text { 3.3 Fasten cables with cable tie }\end{array}$ \\
\hline \multirow[t]{2}{*}{3.1} & $\begin{array}{l}\text { Form cables on marking board } \\
\text { Plan 3.1: Do 3.1.1 then 3.1.2 then exit }\end{array}$ \\
\hline & $\begin{array}{l}\text { 3.1.1 Arrange cables along marked track // } \\
\text { 3.1.2 Fasten cable ends // }\end{array}$ \\
\hline \multirow[t]{2}{*}{3.2} & $\begin{array}{l}\text { Paste marking tape on cables } \\
\text { Plan 3.2: Repeat 3.2.1 then 3.2.2 for two marked locations then exit }\end{array}$ \\
\hline & $\begin{array}{l}\text { 3.2.1 Get marking tape // } \\
\text { 3.2.2 Paste marking tape on marked location // }\end{array}$ \\
\hline 3.3 & $\begin{array}{l}\text { Fasten cables with cable tie } \\
\text { Plan 3.3: Repeat 3.3.1 then 3.3.2 for two marked locations then exit }\end{array}$ \\
\hline
\end{tabular}




\begin{tabular}{|c|c|}
\hline & $\begin{array}{l}\text { 3.3.1 Get cable tie // } \\
\text { 3.3.2 Fasten cable tie on marked location // }\end{array}$ \\
\hline \multirow[t]{2}{*}{4} & $\begin{array}{l}\text { Assemble cables on terminal } \\
\text { Plan 4: Do } 4.1 \text { for two cables then } 4.2 \text { then exit }\end{array}$ \\
\hline & $\begin{array}{l}\text { 4.1 Secure cable ends on terminal } \\
4.2 \text { Set terminal on marking board }\end{array}$ \\
\hline \multirow[t]{2}{*}{4.1} & $\begin{array}{l}\text { Secure cable ends on terminal } \\
\text { Plan 4.1: Do 4.1.1 then repeat 4.1.2 then } 4.1 .3 \text { for two cables then exit }\end{array}$ \\
\hline & $\begin{array}{l}\text { 4.1.1 Get terminal from part tray // } \\
\text { 4.1.2 Hold and locate insertion point // } \\
\text { 4.1.3 Insert cable end into terminal with driver // }\end{array}$ \\
\hline \multirow[t]{2}{*}{4.2} & $\begin{array}{l}\text { Set terminal on marking board } \\
\text { Plan 4.2: Do 4.2.1 then 4.2.2 then exit }\end{array}$ \\
\hline & $\begin{array}{l}\text { 4.2.1 Release terminal } \\
\text { 4.2.2 Get and place terminal on marking board // }\end{array}$ \\
\hline \multirow[t]{2}{*}{5} & $\begin{array}{l}\text { Assemble metal plate } \\
\text { Plan 5: Do } 5.1 \text { then } 5.2 \text { then exit }\end{array}$ \\
\hline & $\begin{array}{l}\text { 5.1 Secure cables on metal plate } \\
5.2 \text { Set metal plate on marking board }\end{array}$ \\
\hline \multirow[t]{2}{*}{5.1} & $\begin{array}{l}\text { Secure cables on metal plate } \\
\text { Plan 5.1: Do 5.1.1 then repeat 5.1.2 then } 5.1 .3 \text { then exit }\end{array}$ \\
\hline & $\begin{array}{l}\text { 5.1.1 Get metal plate from part tray // } \\
\text { 5.1.2 Hold metal plate // } \\
\text { 5.1.3 Fasten cables on metal plate with cable tie // }\end{array}$ \\
\hline \multirow[t]{2}{*}{5.2} & $\begin{array}{l}\text { Set metal plate on marking board } \\
\text { Plan 5.2: Do } 5.2 .1 \text { then } 5.2 .2 \text { then exit }\end{array}$ \\
\hline & $\begin{array}{l}\text { 5.2.1 Release metal plate // } \\
\text { 5.2.2 Get and place metal plate on marking board // }\end{array}$ \\
\hline
\end{tabular}

Table 1. HTA table of the cable harness assembly

\subsection{Collaboration Analysis}

The above task decomposition development based on HTA guideline has provided a coarse task outline of the cable harness assembly. The next step is to conduct detailed analysis for collaboration planning in task level. The analysis can be done in two stages, qualitative and quantitative, based on the complexity to determine the optimum collaboration solution for a given task. In qualitative analysis, the performance requirements of the task are compared qualitatively with the capabilities of human and robot to identify possible collaboration solution. If the optimum solution is not apparent, quantitative analysis can be conducted to score the possible solutions based on the performance requirements.

Qualitative Analysis for Collaboration Task Identification. In qualitative analysis for collaboration task identification, the possible collaboration solution for each task is identified based on the comparison of the strength of human operator and robot manipulator with respect to performance requirements. Together with the definitions by Helms et al. on four types of human-robot cooperation in industrial environment: independent operation, synchronized cooperation, simultaneous cooperation, and assisted cooperation 
(Helms et al., 2002), the collaboration tasks are identified and summarized in Table 2 for the first hierarchical level assembly tasks in cable harness assembly.

The objective of Task 1, 'Prepare parts kit' (Super-ordinate 1) is to gather and arrange the assembly components into parts kit. This objective can be achieved easily by robot system using bin picking technique. Hence, it is suitable to be assigned to robot system for higher efficiency. Task 2, 'Assemble cables on connector' (Super-ordinate 2) requires handling of flexible cables for assembly. Therefore, human operator's flexibility is needed in this task. However, based on previous study (Pongthanya et al., 2008), the mental workload for the human operator to search for the correct insertion holes from the multi-holes connector can be relatively high and time consuming. Therefore, a possible collaboration by using robot system to indicate cable insertion holes by holding the connector under a fixed beam from the laser pointer might be a good solution. However, further quantitative analysis might be needed to justify this collaboration proposal. 'Arrange cables on marking board' in Task 3 (Super-ordinate 3) requires handling of cables, marking tape and cable tie. Hence, these highly flexible operations are suitable to be assigned to human operator. Task 4, 'Assembly cables on terminal' (Super-ordinate 4) has the similar job requirements as in Task 2. Therefore, same collaboration solution might be applied. Task 5, 'Assembly metal plate' (Super-ordinate 5 ) involves operation to fasten the cables on the metal plate with cable ties. A possible collaboration solution might be proposed, which the robot system can help to hold the metal plate to allow the human operator to use both hands to fasten the cables with cable ties.

\begin{tabular}{|l|l|l|}
\hline Super-ordinate & Task components & Collaboration \\
\hline 1 & $\begin{array}{l}\text { Prepare parts kit } \\
\text { 1.1 Arrange parts into tray } \\
1.2 \text { Check parts // }\end{array}$ & $\begin{array}{l}\text { Independent operation by robot } \\
\text { manipulators to prepare the parts } \\
\text { kit }\end{array}$ \\
\hline 2 & $\begin{array}{l}\text { Assemble cables on connector } \\
\text { 2.1 Secure cable contacts on connector } \\
2.2 \text { Temporarily fix cable ends // } \\
\text { 2.3 Set connector on marking board }\end{array}$ & $\begin{array}{l}\text { Assisted cooperation by robot } \\
\text { manipulator to hold the connector } \\
\text { and indicate assembly points while } \\
\text { human operator inserts the cable } \\
\text { contacts }\end{array}$ \\
\hline 3 & $\begin{array}{l}\text { Arrange cables on marking board } \\
\text { 3.1 Form cables on marking board } \\
\text { 3.2 Paste marking tape on cables } \\
3.3 \text { Fasten cables with cable tie }\end{array}$ & $\begin{array}{l}\text { Independent operation by human } \\
\text { operator due to the requirement to } \\
\text { handle flexible cables }\end{array}$ \\
\hline 4 & $\begin{array}{l}\text { Assemble cables on terminal } \\
\text { 4.1 Secure cable ends on terminal } \\
\text { 4.2 Set terminal on marking board }\end{array}$ & $\begin{array}{l}\text { Assisted cooperation by robot } \\
\text { manipulator to hold the terminal } \\
\text { and indicate assembly points while } \\
\text { human operator inserts the cable } \\
\text { ends }\end{array}$ \\
\hline 5 & $\begin{array}{l}\text { Assemble metal plate } \\
\text { 5.1 Secure cables on metal plate } \\
\text { 5.2 Set metal plate on marking board } \\
\text { manipulator to hold the metal } \\
\text { plate while human operator } \\
\text { fastens the cables with cable ties }\end{array}$ \\
\hline
\end{tabular}

Table 2. Collaboration identification from the HTA table

Quantitative Analysis by Analytic Hierarchy Process (AHP). When multiple requirements (productivity, fatigue, safety, etc.) and solutions (human system, robot system, human-robot system, etc.) are available for a given task and the optimum solution might not be apparent 
by qualitative analysis, collaboration analysis by Analytic Hierarchy Process (AHP) [Saaty, 2008; Saaty, 1994] approach can be conducted to assess the task quantitatively. Taking Task 2, 'Assemble cables on connector' (Super-ordinate 2) as example, the following description illustrates the quantitative analysis by AHP to verify the selection of human-robot collaborative system over human only system for the given task.

Four performance requirements, namely, productivity (assembly duration), quality (assembly error), human fatigue (human operator tiredness), and safety (human operation safety), are set as the criteria in the AHP analysis. The evaluation is done based on comparison between human only system and human-robot system as alternatives (fully automated system is less practical to be considered due to the complexity of flexible cable handling in this task). Fig. 4 shows the AHP model of Task 2. In order to compute the priorities (relative weight of the nodes) of criteria and alternatives, pairwise comparison matrix of criteria (Table 3), pairwise comparison matrix of alternatives with respect to productivity (Table 4), quality (Table 5), human fatigue (Table 6), and safety (Table 7) are developed from the analysis. Based on the fundamental scale of pairwise comparisons (Harker \& Vargas, 1987), the intensity of importance values are assigned to the pairwise comparison matrixes by comparing the importance between two criteria. The priorities are then being calculated by summing each row and dividing each by the total sum of all the rows in the corresponding matrix.

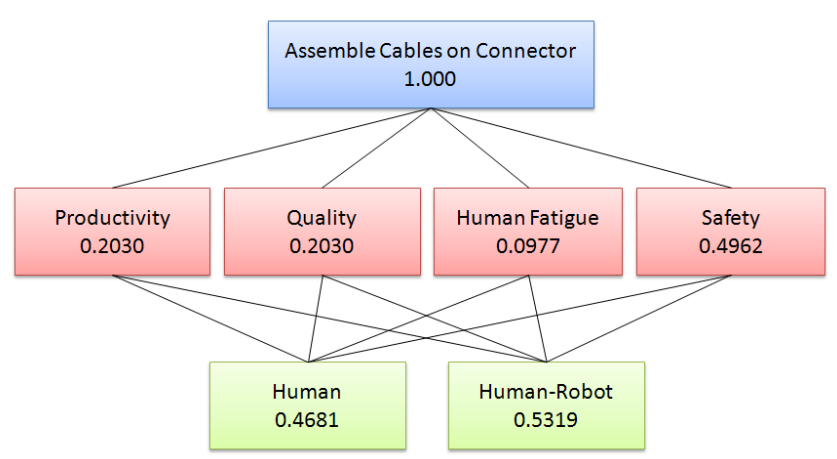

Fig. 4. AHP model of Task 2

From Table 3, the productivity and quality have the same importance (intensity of importance $=1$ ) in achieving the assembly operation (goal). The safety criterion has been given higher priority in the pairwise comparison (intensity of importance $=2$ ) over productivity and quality due to the high risk nature of the close range collaboration. The intensity of importance of productivity and quality over human fatigue also has been set to 2 to put more focus on mental stress of the human operator during close range collaboration with the robot system. The safety has much stronger importance (intensity of importance = 6) over human fatigue. The pairwise comparisons on the alternative systems with respect to each criterion are being judged based on the actual system performance. The improvements from human-robot design can be given a greater importance in the productivity (Table 4) and quality (Table 5). The assistance from robots also greatly reduced the workload burden of the human operator (Table 6). However, due to the close range collaboration, the safety 
level is much lower in human-robot design (Table 7). The final priorities obtained for human system is 0.4681 and human-robot system is 0.5319 (Fig. 4). These have proven that humanrobot system is much preferred solution that fit well to the performance criteria.

\begin{tabular}{|l|c|c|c|c|c|}
\hline & Productivity & $\begin{array}{c}\text { Qualit } \\
\mathbf{y}\end{array}$ & $\begin{array}{c}\text { Human } \\
\text { Fatigue }\end{array}$ & Safety & Priorities \\
\hline Productivity & 1 & 1 & 2 & $1 / 2$ & 0.2030 \\
\hline Quality & 1 & 1 & 2 & $1 / 2$ & 0.2030 \\
\hline Human Fatigue & $1 / 2$ & $1 / 2$ & 1 & $1 / 6$ & 0.0977 \\
\hline Safety & 2 & 2 & 6 & 1 & 0.4962 \\
\hline
\end{tabular}

Table 3. Pairwise comparison matrix of the performance criteria with respect to the goal

\begin{tabular}{|l|c|c|c|c|}
\hline & Human & Human-Robot & $\begin{array}{c}\text { Local } \\
\text { Priorities }\end{array}$ & $\begin{array}{c}\text { Global } \\
\text { Priorities }\end{array}$ \\
\hline Human & 1 & $1 / 9$ & 0.1 & 0.0203 \\
\hline Human-Robot & 9 & 1 & 0.9 & 0.1827 \\
\hline
\end{tabular}

Table 4. Pairwise comparison matrix of the alternative systems with respect to productivity

\begin{tabular}{|l|c|c|c|c|}
\hline & Human & Human-Robot & $\begin{array}{c}\text { Local } \\
\text { Priorities }\end{array}$ & $\begin{array}{c}\text { Global } \\
\text { Priorities }\end{array}$ \\
\hline Human & 1 & $1 / 9$ & 0.1 & 0.0203 \\
\hline Human-Robot & 9 & 1 & 0.9 & 0.1827 \\
\hline
\end{tabular}

Table 5. Pairwise comparison matrix of the alternative systems with respect to quality

\begin{tabular}{|l|c|c|c|c|}
\hline & Human & Human-Robot & $\begin{array}{c}\text { Local } \\
\text { Priorities }\end{array}$ & $\begin{array}{c}\text { Global } \\
\text { Priorities }\end{array}$ \\
\hline Human & 1 & $1 / 6$ & 0.1429 & 0.0014 \\
\hline Human-Robot & 6 & 1 & 0.8571 & 0.0838 \\
\hline
\end{tabular}

Table 6. Pairwise comparison matrix of the alternative systems with respect to human fatigue

\begin{tabular}{|l|c|c|c|c|}
\hline & Human & Human-Robot & $\begin{array}{c}\text { Local } \\
\text { Priorities }\end{array}$ & $\begin{array}{c}\text { Global } \\
\text { Prioritie } \\
\text { s }\end{array}$ \\
\hline Human & 1 & 5 & 0.8333 & 0.4135 \\
\hline Human-Robot & $1 / 5$ & 1 & 0.1667 & 0.0827 \\
\hline
\end{tabular}

Table 7. Pairwise comparison matrix of the alternative systems with respect to safety

Collaboration Role Assignment. After the collaboration solution for each task in the first hierarchical level has been identified and justified, collaboration roles (Human-Robot, Human, and Robot) can be assigned to lower hierarchical task components (Table 8). The assignment can greatly assist the later control plan developments, for instance, robot system programming or human operator operation support development. The task modeling with collaboration planning is then can be completed in the task modeling tool developed in this project (Tan et al., 2009b) with color task role indicators for collaboration relationship visualization as shown in the graphical task model in Fig. 5. 


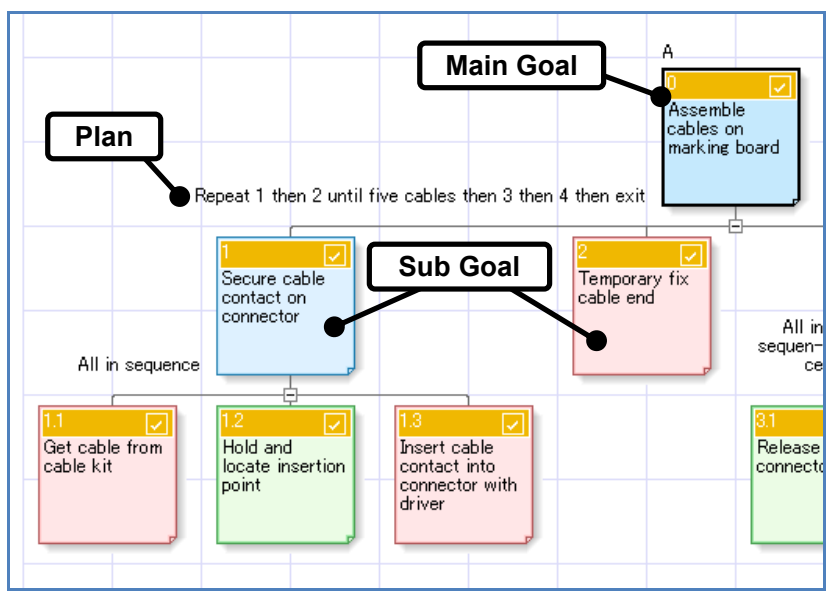

Fig. 5. Task model (partially) of a cable harness assembly (human-robot: blue; human: pink; robot: green)

\begin{tabular}{|l|l|l|}
\hline Super-ordinate & Task components & Collaboration Roles \\
\hline 0 & Assemble cable harness & Human-Robot \\
\hline 1 & Prepare parts kit & Robot \\
1.1 & Arrange parts into tray & Robot \\
1.1 .1 & Retrieve part container & Robot \\
1.1 .2 & Grab part from container & Robot \\
1.2 & Check parts & Robot \\
\hline 2 & Assemble cables on connector & Human-Robot \\
2.1 & Secure cable contacts on connector & Human-Robot \\
2.1 .1 & Get cable from cable kit & Human \\
2.1 .2 & Hold and locate insertion point & Robot \\
2.1 .3 & Insert cable contact into connector with driver & Human \\
2.2 & Temporarily fix cable ends & Human \\
2.3 & Set connector on marking board & Human-Robot \\
2.3 .1 & Release connector & Robot \\
2.3 .2 & Get and place connector on marked location & Human \\
\hline 3 & Arrange cables on marking board & Human \\
3.1 & Form cables on marking board & Human \\
3.1 .1 & Arrange cables along marked track & Human \\
3.1 .2 & Fasten cable ends & Human \\
3.2 & Paste marking tape on cables & Human \\
3.2 .1 & Get marking tape & Human \\
3.2 .2 & Paste marking tape on marked location & Human \\
3.3 & Fasten cables with cable tie & Human \\
3.3 .1 & Get cable tie & Human \\
3.3 .2 & Fasten cable tie on marked location & Human \\
\hline 4 & Assemble cables on terminal & Human-Robot \\
4.1 & Secure cable ends on terminal & Human-Robot \\
4.1 .1 & Get terminal from part tray & Robot \\
4.1 .2 & Hold and locate insertion point & Robot \\
4.1 .3 & Insert cable end into terminal with driver & Human \\
4.2 & Set terminal on marking board & Human-Robot \\
& & \\
\hline
\end{tabular}




\begin{tabular}{|l|l|l|}
4.2 .1 & Release terminal & Robot \\
4.2 .2 & Get and place terminal on marking board & Human \\
\hline 5 & Assemble metal plate & Human-Robot \\
5.1 & Secure cables on metal plate & Human-Robot \\
5.1 .1 & Get metal plate from part tray & Robot \\
5.1 .2 & Hold metal plate & Robot \\
5.1 .3 & Fasten cables on metal plate with cable tie & Human \\
5.2 & Set metal plate on marking board & Human-Robot \\
5.2 .1 & Release metal plate & Robot \\
5.2 .2 & Get and place metal plate on marking board & Human \\
\hline
\end{tabular}

Table 8. Collaboration role assignments

\section{Design Enhancements in Collaboration Planning}

\subsection{Operation Process Design in Collaboration Planning}

From the task analysis in task model, possible collaboration operations can be identified in the assembly level. The collaboration analysis is then further continued into control level to assign the collaboration roles between the working agents in operation. The combination of original Plan components and the added collaboration role assignments has represented the collaboration assembly sequences. The developed task model is used in the assembly and task planning (Barnes et al., 1997; Gottschlich et al., 2002) as well as feasible assembly sequence generations and sequence changes. The following discussion will illustrate the improvements of operation process planning by this work (Tan et al., 2008b) in cable harness assembly.

In the original human only setup of the cable harness assembly, Task 2, 'Assemble cables on connector' requires the human operator to identify the specific insertion hole from a $12 \times 6$ holes connector to insert the cable contact. If each operation consists of five sets of cables with a total of $5 \times 2$ cable contacts, this task can be highly mentally demanding and often causes error insertions especially after a long period of working (Pongthanya et al., 2008). Fig. 6 shows the original assembly operation sequence from Task 2 to Task 3.1.
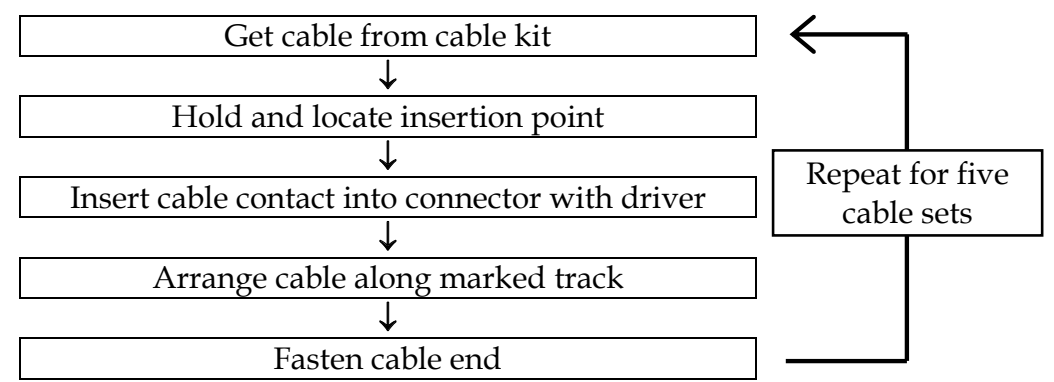

Fig. 6. The initial assembly operation sequence from Task 2 to Task 3.1

Robot system was introduced into the operation to assist the assembly. Without collaboration planning in this work, the robot system was assigned to assist human operator by holding the connector and locating the insertion point. Fig. 7 shows the modified assembly operation sequence after adding the assistance of robot system. 


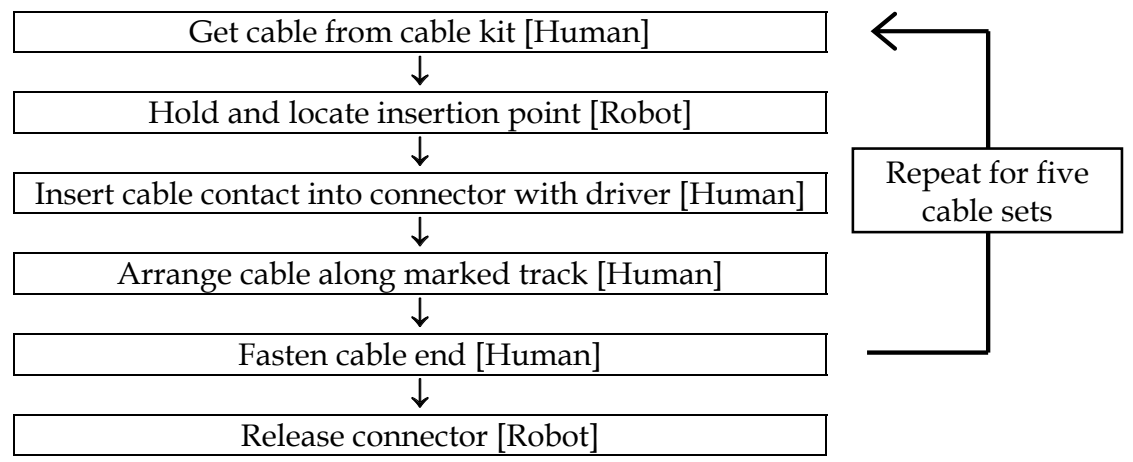

Fig. 7. Modified assembly operation sequence with robot manipulator

One of the most apparent collaboration issues from the above system was the looseness of the cables (or even being pull out from the cable fix) after the release of connector by the robot system at the end of the operation. By redesigning the operation sequence might be able to provide a solution for the issue but direct approach to revise the operation sequence planning is absence without proper task analysis.

From the task analysis and collaboration planning in this work, the cable harness assembly is being decomposed into task sequence and role assigning between human operator and robot system as explained in previous section. Based on the task model (as summarized in Fig. 8), 'Arrange cable along marked track' and 'Fasten cable end', are identified as repetitive steps and can be grouped into two single operation steps outside the operation loop. These steps can be simplified by adding a short step, 'Temporary fix cable end' (Fig. 9) in the operation loop. By placing the two steps at the end of the operation, it will also solve the previous 'loosen cable' issue by fasten the cables after the release of the connector. With this, the operation sequence is being improved while the human-robot collaboration is preserved.
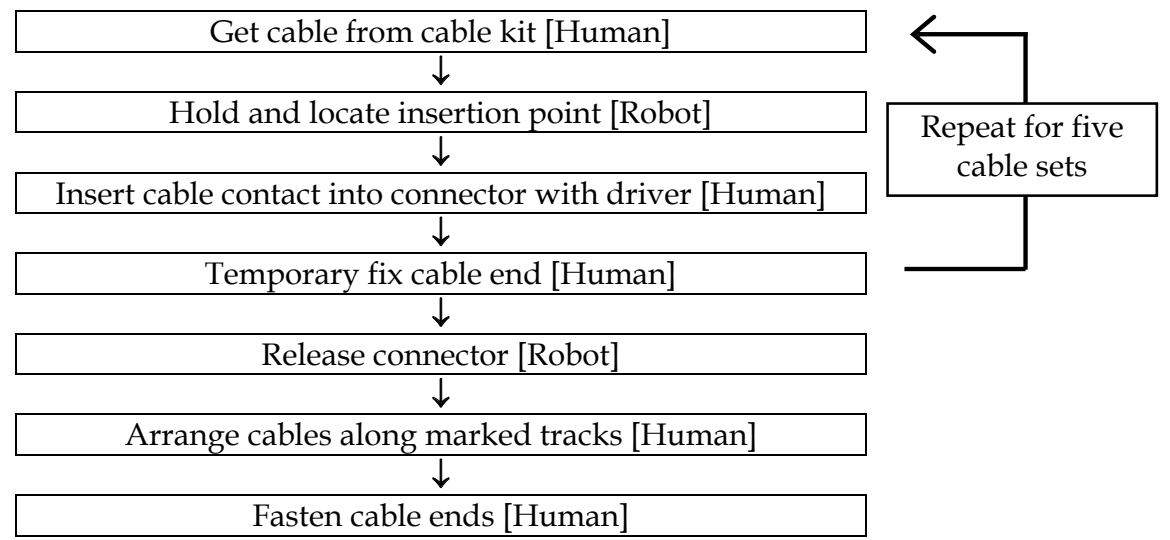

Fig. 8. Assembly operation sequence with task analysis

From the above discussion, the design enhancements in term of (a) group repetitive steps ('Arrange cable along marked track' and 'Fasten cable end'), (b) add interval step ('Temporary fix 
cable end'), and (c) preserve collaboration are achieved by task analysis in collaboration planning. On the other hand, by observing the first hierarchical level of tasks and plan in task modeling (Fig. 10), the precedence relationships among the tasks are well defined (red dotted arrows) to assist possible assembly sequence changes while preserving the assembly process. In the cable harness assembly, Task 3 'Arrange cables on marking board' and Task 4 'Assemble cables on terminal' are independent from each other after Task 2. Hence assembly sequence change is possible in switching the two tasks in the operation flow (Fig. 11). This assembly sequence changed operation is validated by the design implementation in the prototype production cell on the next section.

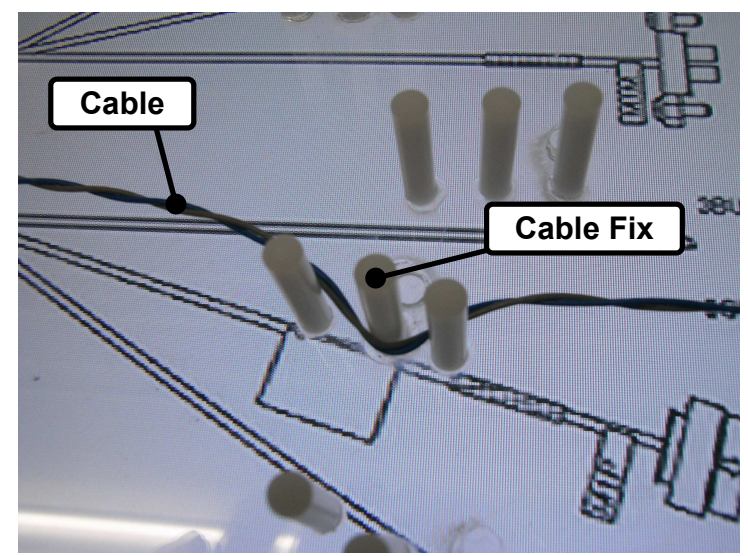

Fig. 9. Temporary cable end fixing on cable fix

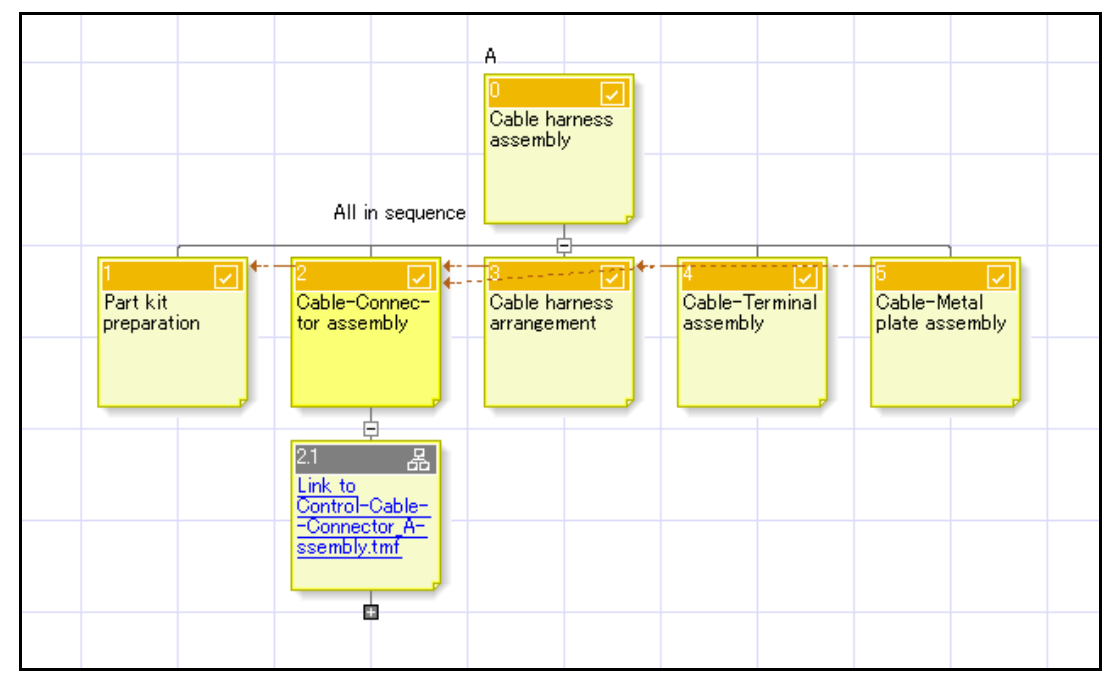

Fig. 10. The first hierarchical level of tasks and plan with precedence relationships (red dotted arrows) 


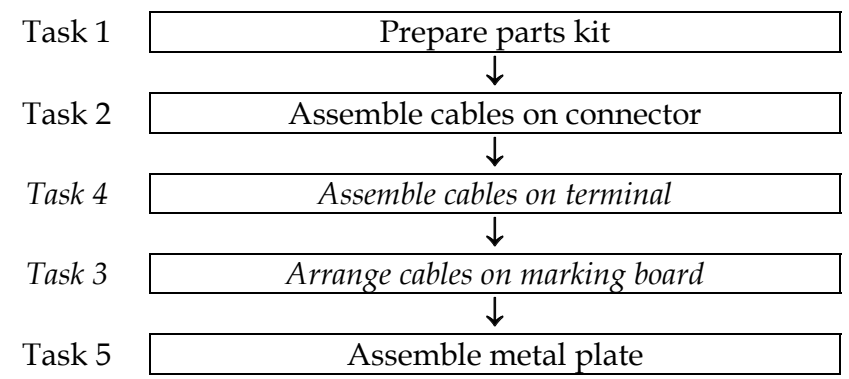

Fig. 11. Cable harness assembly sequence change flow

\subsection{Design Extensions for Human Skill Analysis, Safety Assessment and Operation Support}

The main aim of this work is to enable collaboration planning for human-robot system in manufacturing. By adopting a more human-centered approach, task analysis enables detailed study on production operation to model and design the collaboration process. The developed task model provides several more extensions to further enhance the collaboration.

Human Skill Analysis. In human operation skill study (Duan, 2009), modeling of operation in well structured task model enables further analysis on operator's cognition and motor skill requirements in the corresponding tasks. From the task model of cable harness assembly, potential cognition and motor skills can be extracted for the corresponding tasks (Table 9) in order to evaluate the effective skills for skill transfer. The purpose of skill transfer is to provide support especially to novice operators to improve working performance and collaboration process.

\begin{tabular}{|l|l|l|l|}
\hline $\begin{array}{l}\text { Super- } \\
\text { ordinate }\end{array}$ & Task components & Potential Cognition Skills & Potential Motor Skills \\
\hline 2.1 .1 & $\begin{array}{l}\text { Get cable from cable } \\
\text { kit }\end{array}$ & $\begin{array}{l}\text { - Focus on cable's color } \\
\text { - Focus on position of cable's } \\
\text { head }\end{array}$ & $\begin{array}{l}\text { - Grasp cable's head } \\
\text { - Sit straightly }\end{array}$ \\
\hline 2.1 .3 & $\begin{array}{l}\text { Insert cable contact } \\
\text { into connector with } \\
\text { driver }\end{array}$ & $\begin{array}{l}\text { - Focus on position of the hole } \\
\text { in connector } \\
\text { - Focus on number of the hole } \\
\text { - Focus on force feedback } \\
\text { - Memorize order of holes in } \\
\text { the connector }\end{array}$ & $\begin{array}{l}\text { - Grasp cable's head } \\
\text { - Elbows lower down }\end{array}$ \\
\hline 3.1 .1 & $\begin{array}{l}\text { Arrange cables } \\
\text { along marked track }\end{array}$ & $\begin{array}{l}\text { - Focus on cross route } \\
\text { fixes on positions of cable } \\
\text { - Focus on force feedback }\end{array}$ & $\begin{array}{l}\text { - Left hand holds the } \\
\text { connector, right hand arranges } \\
\text { cables on cable fixes } \\
\text { - Elbows lower down } \\
\text { fixes }\end{array}$ \\
\hline 3.1 .2 & Fasten cable ends & $\begin{array}{l}\text { - Focus on cross route } \\
\text { - Focus on positions of cable } \\
\text { fixes } \\
\text { - Focus on force feedback }\end{array}$ & $\begin{array}{l}\text { - Hold cables while fasten } \\
\text { - Elbows lower down } \\
\text { - Tightly cross cables on cable } \\
\text { fixes }\end{array}$ \\
\hline
\end{tabular}

Table 9. Potential cognition and motor skills for Task 2 and Task 3 
Safety Assessment. Safety is the top most priority in human-robot systems. In the task modeling, safety assessment can be started as early as in the design stage. Task modeling provides a detailed analysis on human operations until lower control level to identify potential operation risk for the collaboration process. From the task model of cable harness assembly, it identifies possible human-robot collaboration in Task 2, Task 4 and Task 5. From the lower control tasks, two potential hazards can be indentified: (a) human operator's hands and/or head being trapped by robot gripper, (b) collision of robot gripper with the human operator. Table 10 shows the risk assessment on these two potential hazards in collaboration (Tan et al., 2009a) based on industrial standards ANSI/RIA R15.06 (ANSI/RIA, 1999) with reference to ISO 14121 (JIS B9702), ISO 13849-1 (JIS B9705-1), and BS EN 954-1.

\begin{tabular}{|c|c|c|c|c|c|c|}
\hline \multirow[b]{2}{*}{$\begin{array}{c}\text { Task } \\
\text { Description }\end{array}$} & \multirow[b]{2}{*}{ Hazard } & \multicolumn{4}{|c|}{ Prior to safeguard } & \multirow{2}{*}{ 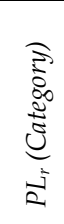 } \\
\hline & & 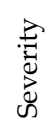 & 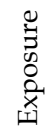 & 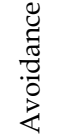 & 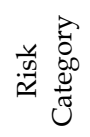 & \\
\hline \multirow{4}{*}{$\begin{array}{l}\text { Cable } \\
\text { harness } \\
\text { assembly } \\
\text { (Task 2, } 4 \\
\text { and 5) }\end{array}$} & Trapped Risk - Hands & S2 & E2 & A2 & R1 & $e(4)$ \\
\hline & Trapped Risk - Head & S2 & E1 & A2 & R2B & $d(3)$ \\
\hline & Collision Risk - Hands & S2 & E2 & A2 & R1 & $e(4)$ \\
\hline & Collision Risk - Head & $\mathrm{S} 2$ & E1 & A2 & $\mathrm{R} 2 \mathrm{~B}$ & $d(3)$ \\
\hline
\end{tabular}

Table 10. Risk assessment on cable harness assembly (Task 2, Task 4 and Task 5)

Operation Support. One unique development in this work is to support operation by providing information to the human operator. Due to the shifting operation support from physical support, which is mainly taken care by automation, information support is one of the important factors that determine operator's working performance. In the prototype production cell for cable harness assembly in this work, a multimodal information support system (Duan et al., 2008) is developed as a man-machine interface for the human-robot collaboration system. However, in order to ensure effective information support, the content of the information has to be appropriate and relevance to the operation. Task modeling in this work has the function to extract and manage the information together with the task model. A task modeling editor (Tan et al., 2009b) (Fig. 12) is built on IBM Task Modeler Version 6 as the development environment of task modeling. An operation properties system is developed to encapsulate relevance information to the task according to the modeling levels and support requirements. Table 11 shows the basic operation properties in the task modeling for the support information development to support the assembly operations in the prototype production cell.

\begin{tabular}{|l|l|l|}
\hline Modeling Level & Operation Properties & Description \\
\hline Assembly & Part & Required component \\
\cline { 2 - 3 } & Sub-assembly & Output of the task \\
\hline \multirow{3}{*}{ Control } & Agent & Subject \\
\cline { 2 - 3 } & Object1 & Direct object \\
\cline { 2 - 3 } & Object2 & Indirect or secondary object \\
\hline
\end{tabular}




\begin{tabular}{|c|c|c|}
\hline & Tool & Support instrument \\
\hline & Jig and Fixture & Support hardware \\
\hline & Operation Duration & Time needed for the operation \\
\hline & Precedence & Precedence relationship \\
\hline \multirow[t]{2}{*}{ Information Support } & $\begin{array}{l}\text { Operation } \quad \text { Reference } \\
\text { Media }\end{array}$ & $\begin{array}{l}\text { Reference description in any } \\
\text { media format }\end{array}$ \\
\hline & Safety & Safety information \\
\hline
\end{tabular}

Table 11. Operation properties in task modeling

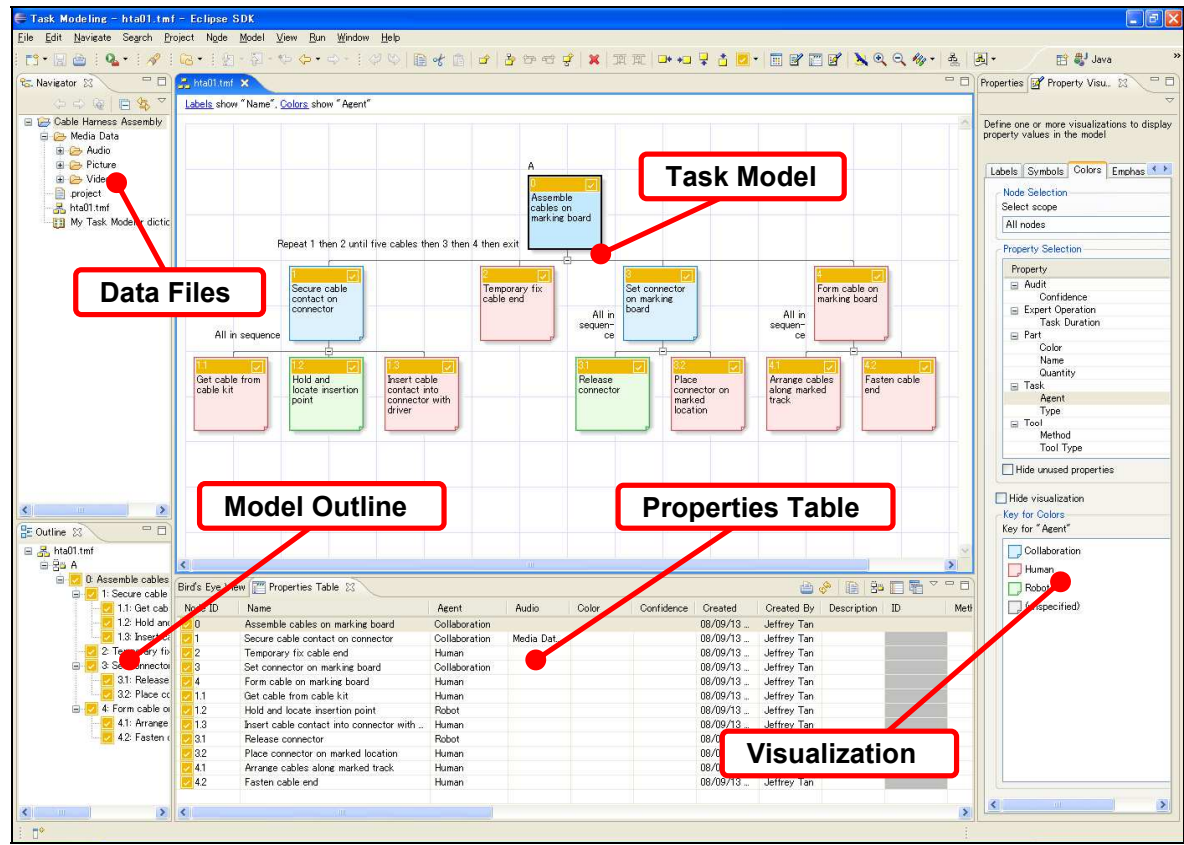

Fig. 12. Task modeling editor user interface

\section{Design Implementation and Operation Performance Evaluation}

An actual prototype production cell for cable harness assembly (Fig. 13) is developed as design implementation to conduct validation study on the task model and collaboration planning. From the task model, low level control plan is developed to program the robot system and to generate information support to instruct the human operator during operation. From the implementation operation, the cable harness assembly operation was successfully being completed by the human-robot system based on the proposed collaboration planning. A second set of operation with the assembly sequence changed in switching Task 3 and Task 4 (Section 4.1) was also successfully being conducted to validate the assembly sequence planning in task modeling.

Operation performance evaluation was also carried out based on the comparison results between conventional manual assembly setup (Exp I) and the new human-robot collaboration setup (Exp II) in Fig. 13. A group of novice and expert operators (7 males, 22- 
36 years old) had performed the assembly three times each in each of the two setups to obtain the time needed to complete the operations.

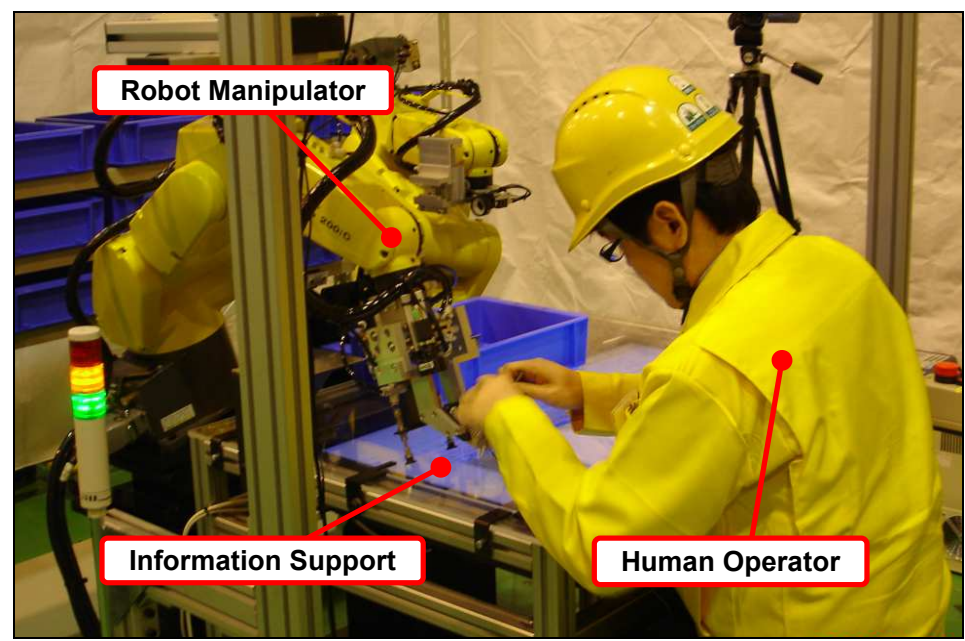

Fig. 13. Prototype production cell setup

From the results in Fig. 14, the overall performance was improved with shorter assembly duration in collaboration setup (Exp II). In the collaboration setup (Exp II), novice and expert operators had almost the same assembly duration, which meant best performance was made possible even for novice operators, who in conventional setup (Exp I) require almost double the time in first trial. The improvement in assembly quality, from $10 \%$ to $20 \%$ of assembly error (insertion error) in conventional setup (Exp I) to assembly error was totally being prevented in collaboration setup (Exp II), had proven the effectiveness of the collaboration.

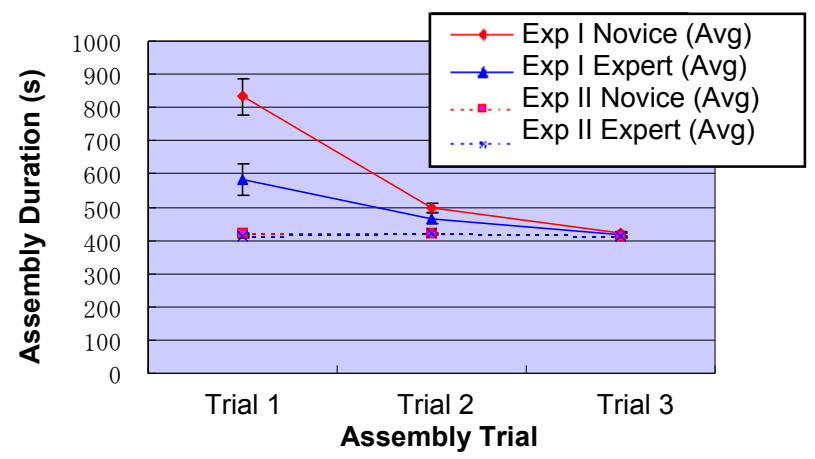

Fig. 14. Results of assembly duration in conventional setup (Exp I) and collaboration setup (Exp II) 


\section{Conclusions and Future Work}

The challenge of this work is to develop collaboration planning between human operator and robot system in a collaborative manufacturing system by task analysis approach. The development is worked in parallel with a cable harness assembly operation in a prototype cellular manufacturing system. The core developments of this study are summarized as the following:

(a) Task decomposition by hierarchical task analysis - by using the capability of HTA, the entire operation is being decomposed into structured hierarchical tasks tree.

(b) Collaboration analysis - qualitative and quantitative analyses are conducted to identify and justify the possible collaborative solutions from the task model to further define the details of collaboration. Collaboration roles are assigned to all task components with color task role indicators to improve the collaboration relationship representation of the task model.

(c) Design enhancements in operation process design - improvements in term of (a) group repetitive steps, (b) add interval step, (c) preserve collaboration, and (d) assembly sequence changes are achieved in the task modeling of cable harness assembly.

(d) Design extensions in human skill analysis, safety assessment and operation support - extensions in facilitate human cognitive and motor skills studies, conduct risk assessment for safety design and assist information support development.

(e) Practical implementation in prototype system - model validation was conducted successfully with an actual cable harness assembly operation and positive results were obtained in the operation performance evaluation.

This work might have completed a preliminary modeling framework for human-robot collaboration planning in manufacturing systems based on task analysis approach. More research studies and developments are needed to further enhance the work:

(a) Quantitative studies should be conducted to investigate the effectiveness of the human-robot collaboration planning.

(b) Comparison study with other production operations to investigate the modeling capability of the proposed framework.

(c) The temporal aspects in collaboration should be taken into consideration to develop a more realistic representation for asynchronous human-robot operations.

\section{References}

Agah, A. (2000). Human interactions with intelligent systems: research taxonomy, Computers E Electrical Engineering, Vol. 27, No. 1, pp. 71-107

Annett J. \& Duncan, K. D. (1967). Task analysis and training design, Occupational Psychology, Vol. 41, pp. 211-221

ANSI/RIA R15.06 (1999). Industrial Robots and Robot Systems - Safety Requirements, American National Standards Institute / Robotic Industries Association

Barnes, C. J.; Dalgleish, G. F.; Jared, G. E. M.; Swift, K. G. \& Tate, S. J. (1997). Assembly sequence structures in design for assembly, Proceedings of the IEEE International Symposium on Assembly and Task Planning, pp. 164-169 
Bischoff, R. (2001). System Reliability and Safety Concepts of the Humanoid Service Robot HERMES, Proceedings of the First IARP/IEEE-RAS Joint Workshop on Technical Challenge for Dependable Robots in Human Environments

Colgate, J. E.; Wannasuphoprasit, W. \& Peshkin, M. A. (1996). Cobots: Robots for Collaboration with Human Operators, Proceedings of the International Mechanical Engineering Congress and Exhibition, pp. 433-439

Duan, F. (2009). Assembly Skill Transfer System for Cell Production, PhD thesis, University of Tokyo, Japan

Duan, F.; Morioka, M.; Tan, J. T. C. \& Arai, T. (2008). Multi-modal Assembly-Support System for Cell Production, International Journal of Automation Technology, Vol. 2, No. 5, pp. 384-389

Gottschlich, S.; Ramos, C. \& Lyons, D. (2002). Assembly and task planning: a taxonomy, IEEE Robotics \& Automation Magazine, Vol. 1, No. 3, pp. 4-12

Helms, E.; Schraft, R. D. \& Hagele, M. (2002). rob@work: Robot assistant in industrial environments, Proceedings of $11^{\text {th }}$ IEEE International Workshop on Robot and Human Interactive Communication, pp. 399-404

Harker, P. T. \& Vargas, L. G. (1987). The theory of ratio scale estimation: Saaty's analytic hierarchy process, Management Science, Vol. 33, No. 11, pp. 1383-1403

Hodgkinson, G. P. \& Crawshaw, C. M. (1985). Hierarchical task analysis for ergonomics research, Applied Ergonomics, Vol. 16, No. 4, pp. 289-299

Hollnagel, E. (2006). Chapter 14 task analysis: why, what, and how, In: Handbook of Human Factors and Ergonomics, Third Edition, pp. 373-383, John Wiley \& Sons, Inc.

Iossifidis, I.; Bruckhoff, C.; Theis, C.; Grote, C.; Faubel, C.; Schoner, G. (2002). CORA: An Anthropomorphic Robot Assistant for Human Environment, Proceedings of the IEEE International Workshop on Robot and Human Interactive Communication, pp. 392-398

Isa, K. \& Tsuru, T. (2002). Cell production and workplace innovation in Japan: towards a new model for Japanese manufacturing? Industrial Relations, Vol. 41, No. 4, pp. 548578

Killich, S.; Luczak, H.; Schlick, C.; Weissenbach, M.; Wiendemaier, S. \& Ziegler, J. (1999). Task modeling for cooperative work, Behaviour and Information Technology, Vol. 18, No. 5, pp. 325-338

Kirwan, B. \& Ainsworth, L. K. (1992). A Guide to Task Analysis, Taylor \& Francis, London

Kosuge, K.; Hashimoto, S. \& Yoshida, H. (1998). Human-robots collaboration system for flexible object handling, Proceedings of the IEEE International Conference on Robotics and Automation, Vol. 2, pp. 1841-1846

Kosuge, K.; Yoshida, H.; Taguchi, D.; Fukuda, T.; Hariki, K.; Kanitani, K. \& Sakai, M. (1994). Robot-human collaboration for new robotic applications, Proceedings of the 20 th International Conference on Industrial Electronics, Control, and Instrumentation, Vol. 2, pp. 713-718

Laengle, T.; Hoeniger, T. \& Zhu, L. (1997). Cooperation in Human-Robot-Teams, Proceedings of the IEEE International Symposium on Industrial Electronics, pp. 1297-1301

Lane, R.; Stanton, N. A. \& Harrison, D. (2006). Applying hierarchical task analysis to medication administration errors, Applied Ergonomics, Vol. 37, No. 5, pp. 669-679

Mills, S. (2007). Contextualizing design: aspects of using usability context analysis and hierarchical task analysis for software design, Behaviour $\mathcal{E}$ Information Technology, Vol. 26, pp. 499-506 
Mizoguchi, F.; Hiraishi, H. \& Nishiyama, H. (1999). Human-robot collaboration in the smart office environment, Proceedings of IEEE/ASME International Conference on Advanced Intelligent Mechatronics, pp. 79-84

Oborski, P. (2004). Man-machine interactions in advanced manufacturing systems, International Journal of Advanced Manufacturing Technology, Vol. 23, No. 3-4, pp. 227232

Pongthanya, N.; Duan, F.; Tan, J. T. C.; Watanabe, K.; Zhang, Y.; Sugi, M.; Yokoi, H. \& Arai, T. (2008). Evaluating assembly instruction methods in cell production system by physiological parameters and subjective indices, Proceedings of The 41st CIRP Conference on Manufacturing Systems, pp. 199-202

Richardson, J.; Ormerod, T. C. \& Shepherd, A. (1998). The role of task analysis in capturing requirements for interface design, Interacting with Computers, Vol. 9, No. 4, pp. 367384

Rudas, I. J. \& Horvath, L. (1996). Modeling man-machine processes in CAD/CAM and flexible manufacturing systems, Proceedings of the $22^{\text {nd }}$ IEEE International Conference on Industrial Electronics, Control, and Instrumentation, Vol. 3, pp. 1484-1489

Saaty, T. L. (2008). Decision making with the analytic hierarchy process, International Journal of Services Sciences, Vol. 1, No. 1, pp. 83-98

Saaty, T. L. (1994). How to make a decision: The analytic hierarchy process, Interfaces, Vol. 24, No. 6, pp. $19-43$

Sarker, S. K.; Chang, A.; Albrani, T. \& Vincent, C. (2008). Constructing hierarchical task analysis in surgery, Surgical Endoscopy, Vol. 22, No. 1, pp. 107-111

Shepherd, A. (1998). HTA as a framework for task analysis, Ergonomics, Vol. 41, No. 11, pp. $1537-1552$

Stahre, J. (1995). Evaluating human/machine interaction problems in advanced manufacturing, Computer-Integrated Manufacturing Systems, Vol. 8, No. 2, pp. 143150

Stanton, N. A. (2006). Hierarchical task analysis: developments, applications, and extensions. Applied Ergonomics, Vol. 37, No. 1, pp. 55-79, 2006

Stopp, A.; Baldauf, T.; Hantsche, R.; Horstmann, S.; Kristensen, S.; Lohnert, F.; Priem, C.; Ruscher, B. (2002). The Manufacturing Assistant: Safe, Interactive Teaching of Operation Sequences, Proceedings of the IEEE International Workshop on Robot and Human Interactive Communication, pp. 386-391

Tan, J. T. C.; Duan, F.; Zhang, Y.; Kato, R. \& Arai, T. (2009a). Safety Design and Development of Human-Robot Collaboration in Cellular Manufacturing, Proceedings of the $5^{\text {th }}$ Annual IEEE Int. Conf. on Automation Science and Engineering, Bangalore, India, pp. 537-542

Tan, J. T. C.; Duan, F.; Zhang, Y.; Kato, R. \& Arai, T. (2009b). Task Modeling Approach to Enhance Man-Machine Collaboration in Cell Production, Proceedings of the IEEE International Conference on Robotics and Automation, pp. 152-157

Tan, J. T. C.; Duan, F.; Zhang, Y. \& Arai, T. (2008a). Extending Task Analysis in HTA to Model Man-Machine Collaboration in Cell Production, Proceedings of the IEEE International Conference on Robotics and Biomimetics, pp. 542-547

Tan, J. T. C.; Duan, F.; Zhang, Y. \& Arai, T. (2008b). Task Decomposition of Cell Production Assembly Operation for Man-Machine Collaboration by HTA, Proceedings of the IEEE International Conference on Automation and Logistics, pp. 1066-1071 


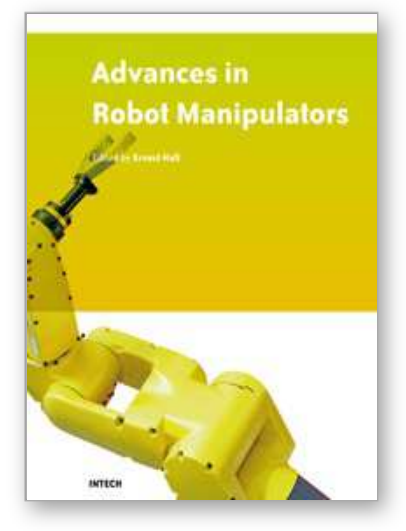

\author{
Advances in Robot Manipulators \\ Edited by Ernest Hall
}

ISBN 978-953-307-070-4

Hard cover, 678 pages

Publisher InTech

Published online 01, April, 2010

Published in print edition April, 2010

The purpose of this volume is to encourage and inspire the continual invention of robot manipulators for science and the good of humanity. The concepts of artificial intelligence combined with the engineering and technology of feedback control, have great potential for new, useful and exciting machines. The concept of eclecticism for the design, development, simulation and implementation of a real time controller for an intelligent, vision guided robots is now being explored. The dream of an eclectic perceptual, creative controller that can select its own tasks and perform autonomous operations with reliability and dependability is starting to evolve. We have not yet reached this stage but a careful study of the contents will start one on the exciting journey that could lead to many inventions and successful solutions.

\title{
How to reference
}

In order to correctly reference this scholarly work, feel free to copy and paste the following:

Jeffrey Too Chuan Tan, Feng Duan, Ryu Kato and Tamio Arai (2010). Collaboration Planning by Task Analysis in Human-Robot Collaborative Manufacturing System, Advances in Robot Manipulators, Ernest Hall (Ed.), ISBN: 978-953-307-070-4, InTech, Available from: http://www.intechopen.com/books/advances-in-robotmanipulators/collaboration-planning-by-task-analysis-in-human-robot-collaborative-manufacturing-system

\section{INTECH}

open science | open minds

\section{InTech Europe}

University Campus STeP Ri

Slavka Krautzeka 83/A

51000 Rijeka, Croatia

Phone: +385 (51) 770447

Fax: +385 (51) 686166

www.intechopen.com

\section{InTech China}

Unit 405, Office Block, Hotel Equatorial Shanghai

No.65, Yan An Road (West), Shanghai, 200040, China

中国上海市延安西路65号上海国际贵都大饭店办公楼405单元

Phone: +86-21-62489820

Fax: $+86-21-62489821$ 
(C) 2010 The Author(s). Licensee IntechOpen. This chapter is distributed under the terms of the Creative Commons Attribution-NonCommercialShareAlike-3.0 License, which permits use, distribution and reproduction for non-commercial purposes, provided the original is properly cited and derivative works building on this content are distributed under the same license. 